\title{
sciendo
}

\section{Of Anthropophagy and Anthropology: Monsters and Men in Beowulf and Northwest Coast Myth and Ritual}

\author{
MICHAEL E. HARKIN \\ Department of Anthropology, \\ University of Wyoming, USA \\ harkin@uwyo.edu
}

\begin{abstract}
Monsters can be divided into two categories: human-like and non-human. Non-human monsters tend to be chthonic beings that are associated with the earth and natural forces. Humanoid monsters represent metaphorical transformations of humanity itself, and as such reveal basic cultural values, such as sociability, while displaying their opposite. Humanoid monsters are the more terrifying, precisely because we recognize ourselves in them, although in an uncanny refraction. In the epic poem Beowulf and in myth and ritual of the Kwakiutl and Heiltsuk cultures of the Northwest Coast, manlike monsters play a central role.
\end{abstract}

KEY WORDS: anthropology, anthropophagy, Beowulf, monsters, myth, Native Americans, Northwest Coast, ritual

\section{Human-like and Non-Human Monsters}

At the very beginning of Anglo-Saxon literary culture, we see a pronounced dichotomy between two types of monster, which structures the poem itself (Tolkien 1983). Early on in Beowulf, the hero must drive away a human-like monster who as a member of the "clan of Cain" is cursed to live apart from humanity with only his mother; looking in at human society from the outside engenders in Grendel a desire to destroy all that he sees and yearns for (Heaney 2008). In his old age, Beowulf must fight a dragon. Both creatures present an 
existential threat to society; beyond that, though, the natures of the two creatures are very different. The dragon lives inside a mountain, is dormant for centuries, sleeping on his hoard, and only very occasionally awakening to create havoc. Grendel, on the other hand, lives much as other humans, with the exception that he is denied the commensality and sociability of human society. It is reasonable, then, to think of the dragon as a chthonic being: it shares the space and temporality of the earth itself. It exists apart from humans gladly, and only when disturbed by human intrusions does it strike out. Its appearance is akin to a natural disaster, such as a volcanic eruption or earthquake. While dragons, as a motif stretching across northern Eurasia from Greenland to China, are certainly important in any general consideration of monsters, I would turn instead to Grendel, because it is here that we see the role of monsters at the heart of human conceptions of self and other.

Grendel is morphologically a human male. He lives with his mother in a reduced version of human society. His only distinctive physical feature is his "superhuman" strength. The author of Beowulf explains that this is part of the curse that God has placed on him as a member of the clan of Cain:

Grendel was the name of this grim demon

haunting the marches, marauding around the heath

and the desolate fens; he had dwelt for a time

in misery among the banished monsters,

Cain's clan, whom the Creator had outlawed

and condemned as outcasts. For the killing of Abel

Cain got no good from committing that murder

because the Almighty made him anathema

and out of the curse of his exile there sprang

ogres and elves and evil phantoms

and the giants too who strove with God

time and again until He gave them their reward (Heaney 2008, 9).

Grendel is in the same category as giants, elves, trolls, and all the other uncanny creatures inhabiting the northern medieval world. These all are examples of what I have elsewhere called, in reference to the "Plinian Races," metaphorical transformations of human nature 
(Harkin 2011). ${ }^{1}$ In the case of Plinian Races, such as the Blemmyae and the Cyclops, these were morphological transformations of the human form (Friedman 2000; Jahoda 1999). Interestingly, in Grendel's case, it is primarily the moral and, if we can use this term in this context, "cultural" dimensions which are transformed. The curse of Cain has degraded these creatures: in some ways physically, as these monsters are considered ugly and are often deformed and giant, but it is clear from the passage above that the defining quality is moral and social (Friedman 2000, 85). They are "condemned as outcasts" and so stand apart from human society, looking in with anger and envy:

\section{It harrowed him}

to hear the din of the loud banquet

every day in the hall, the harp being struck

and the clear song of a skilled poet

telling with mastery of man's beginnings (Heaney 2008, 9).

The banquet hall is a physical place from which Grendel is barred, but more than that, it is the epitome of the positive values of human society. For the Shield-Danes, the overarching values were solidarity and loyalty among the warriors and between them and their king. This was epitomized by the feasting, drinking, and gift giving that took place in the mead hall. It was this which particularly irritated Grendel, who was doomed to a life outside the glittering hall, except for when he could occupy it through force. Even then, he is denied the essence of the place: of course, there are no others with whom to share food, drink, and song, and the throne, the place from which the magic of the place originates, is withheld from Grendel by God himself:

He took over Heorot, haunted the glittering hall after dark,

1 I argue that the European perception of the indigenous peoples of the Americas in the $16^{\text {th }}$ century was characterized by a principle of metaphorical substitution of features of human existence, both morphological and moral, as seen from the European perspective: in other words, monsterology. By the end of the $16^{\text {th }}$ century, with the accounts by John White and Thomas Hariot, published by Theodor De Bry, this had been replaced by a metonymic anthropology. 
but the throne itself, the treasure-seat,

he was kept from approaching; he was the Lord's outcast (Heaney 2008, 13).

What can we say about Grendel qua monster? His physical prowess is terrifying certainly, but what is it that gives him so strongly the uncanny quality characteristic of all monsters? Why do we fear him (more, in Beowulf than the dragon which in fact kills the hero)? It is because he is recognizable as one of us, and yet lacks, and in fact negates, what is seen as the essential feature of humanity. In this case, it is the militaristic, masculine solidarity of the feasting hall that Grendel lacks. More than this, he is a cannibal, which is the precise inversion of the Spear-Danes' practice of commensality. Rather than eat with comrades, he consumes them. We suspect, as well, a second taboo is violated: that of incest with the mother (Earl 2010). As Lévi-Strauss would say, he is undervaluing ties of common humanity and overvaluing those of kinship! (Lévi-Strauss 1967). Sigmund Freud, in his essay on the uncanny ( "unheimlich") suggests that we are terrified by these monsters because they project our own repressed urges and simultaneous fear of punishment for those urges. The word "heimlich" itself reflects a troubling ambiguity; it can mean at once familiar and homelike, as well as hidden. The idea that what is hidden may be exposed carries with it an implicit anxiety. The modification of the word with the prefix un- heightens rather than resolves the ambiguity (Freud 1919).

Grendel is, then, the embodiment of all that the Shield-Danes find repugnant, but which in a Freudian reading represents repressed urges. The medieval and early modern world was full of such monsters, wild men who lived the woods without clothes or civilization, and who were almost universally considered cannibalistic.

Grendel is thus one of a long line of monsters, real and imagined, who live outside the social order and reflect inversions of its key features. These monsters are usually "loners," who perhaps live alone or with their mother, who not only kill but cannibalize or abuse the bodies sexually. Hannibal Lecter, Jeffrey Dahmer, and countless others are instantiations of the Grendel archetype. The horror they evoke comes from our recognition of ourselves in them, but devoid of that which we thought essential to our being. They are not unlike zombies who seem to be able to function without a working brain. This reflects a realistic understanding of what is, in fact, required for society as a whole to function: the repression of urges tending toward murder, cannibalism, and incest. On the collective level, society could not exist without such repression, as Freud argues in Civilization and Its Discontents (Freud 1961). However, individuals may well transgress these taboos, producing in the rest of us feelings of disgust, horror, and fascination. Indeed, we can take this analysis a step further, as Charles Nuckolls has suggested. Rather than posit a singular and simple ethos of a culture, we should 
be sensitive to the fact that within such an ethos is at base a contradiction. Culture is always paradoxical, resting often on contradictory values (as in the United States, between individualism and egalitarianism). Thus, as Freud suggested, the very conditions of life in society are ultimately unreconcilable. Monsters are a reflection of our awareness at some level of this paradox (Nuckolls 1998).

It must be said that while there are global qualities to these monsters (the incest taboo and taboo on cannibalism are virtually universal), there are decidedly cultural variants as well. Thus, in China, a society which places the highest value on children and family, a rash of mass killings at schools erupted in the mid-to-late 2000s. In the United States, where personal autonomy is valued above all, captivity and imprisonment are features of many of the most famous fictional and non-fictional mass murders. In the U.K., which places high value on social cooperation and regularity, spur-of-the-moment outbursts of violence, à la Clockwork Orange strike with particular horror and fascination. The point is, then, that the specific ethos of a society has its own particular negative image or refraction. This negative image in turn provides the archetype of the humanoid monster. Monsterology is thus closely related to (and, I would argue, gives rise to) anthropology proper. Monsters are a way of understanding the structure of a particular cultural and social system of organization, by pointing to that which it is precisely not.

Claude Lévi-Strauss made a similar point when it came to the mythology of Native North America (Lévi-Strauss 1983, 146-197) (interestingly, although dragons are wholly absent from north of Mexico - I suppose Quetzlcoatl of the Aztecs of Mesoamerica could be viewed as one - humanoid monsters are ubiquitous here). Thus Raven, a walking, flying id, is shown in a series of humorous stories to be utterly foolish, and to represent the opposite of the way people should behave; Raven is a slave to his sexual and gustatory pleasures, and things never end well for him. Children are told these stories complete with their sexual embellishments for didactic purposes; indeed, these stories, through the interaction of speaker and audience, recreate the totality of the moral universe in their telling (Hymes 2003, 85). Monsters such as Coyote and Raven (who is both humanoid and avian) find themselves in various sorts of tight spots, the result of transgressing essential cultural rules, most notably sexual and food taboos (Hymes 2003, 289). The audience understands that behavior outside the bounds of cultural norms is not only improper, but ultimately impossible.

\section{Northwest Coast Culture as Analogue to the World of Beowulf}

Northwest Coast society (and here, I necessarily simplify and ignore considerable local variation) was a chiefly society, based on families and clans connected with particular 
hereditary chiefs. Everyone lived in large houses, with poorer relatives of the chief sleeping in the common areas of the big house. It was an oral culture, with a custom of storytelling that connected title-holders with specific territories and property, both material and symbolic. These rights and privileges were validated in public displays involving the giving away of great amounts of wealth, and feasting on salmon and other foods (what comes to be called the "potlatch" in the colonial period). The economy was based almost exclusively on fishing. Warfare was common, both to defend territory and to raid other tribes for wealth and to take slaves. Our mind turns easily from this to Viking raids, the moot, and feasting and give-aways in the Heorot hall. Not surprisingly, we find an ethos very similar to that of the Spear-Danes. The warrior ethic was pervasive; the quotation from Beowulf could have easily been uttered by a Northwest Coast nobleman:

It is always better

to avenge dear ones than to indulge in mourning.

For every one of us, living in this world

means waiting for our end. Let whoever can

win glory before death. When a warrior is gone,

that will be his best and only bulwark (Heaney 2008, 95).

Similarly, the emphasis on feasting and gift-giving was almost identical, down to the description of the wealth as "glittering." Copper was the essence of wealth for the Northwest Coast people; it played a role similar to gold in Beowulf, as a manifestation of inherent value but not yet a form of currency. Gift-giving was the essence of what it meant to be a chieftain in both societies; in Beowulf, Hrothgar the chieftain of the Shield-Danes contrasts Beowulf's generosity (and implicitly his own) with a stingy king:

Heremod was different,

the way he behaved to Ecgwala's sons.

His rise in the world brought little joy

to the Danish people, only death and destruction.

He vented his rage on men he caroused with,

killed his own comrades, a pariah king

who cut himself off from his own kind, 
even though almighty God had made him

eminent and powerful and marked him from the start

for a happy life. But a change happened,

he grew bloodthirsty, gave no more rings

to honour the Danes (Heaney 2008, 117).

To refuse to give away wealth is to overturn the very principle of chieftainship, and to void the ties with the people based on the redistribution of wealth. Thus Heremod is "a pariah king," a minor version of Grendel himself, who kills his own men. Similar stories in Northwest Coast mythology tell of chiefs who terrorize their own people and are thus not legitimate. It is worth pointing out here that the ending of Beowulf, with the hero dead after battling the dragon, is doubly gloomy: the Geats are doomed and the dragon treasure, rather than being distributed to the people as Beowulf had wished, is buried with him. To hoard wealth is to act as a monster rather than a human, and to negate the core value - in both the economic and moral sense - of human society (Robinson 1991).

In this densely forested land of islands and fiords, where human settlements constituted the merest interruption of the misty and dark (especially in winter) world, who existed beyond the light of the village, perhaps peering in with envy and hatred? The forest, along with other realms outside human control, notably the sea and uplands, was teeming with creatures that from our modern perspective would be considered supernatural. However, given the fact that the people of the Northwest Coast fully believed in these creatures, as the Danes and AngloSaxons no doubt believed in Grendel and the dragon, and acted accordingly, it makes sense to think of them as "other than human beings," in A. Irving Hallowell's turn of phrase (Hallowell 1955). Indeed, whenever one ventured from the relative safety of the village, one stood a chance of encountering such beings. Most Northwest Coast oral literature thus takes on aspects of the epic quest, since even the most prosaic journey, such as a trip to the mountains to hunt goats, took on a cosmic dimension. The hero leaves the human world for a separate and distinct world, organized not around humans but around other than human beings. Indeed, it is a separate space-time, what Bakhtin called a "chronotope," possessing the Einsteinian principles of relativity and space-time curving back on itself (Bakhtin 1981). Thus, it is not uncommon for a hero to venture into such a realm and return, Rip van Winklelike, long after he set out, although his perception of time had the journey lasting only a matter of days. 
A journey outside the village was always then a type of quest possessing a decidedly doubleedged quality. Among the Heiltsuk stories were told of someone walking just outside the village, not far away at all, who came upon a hole in the ground. Out of curiosity, he ventured into the chthonian realm, never returning to the village, his remains reduced to a bare skeleton. As with the ancient Greeks, for the Northwest Coast peoples portals to other worlds were common across the landscape. The dangers, especially to the curious and ill-prepared, of venturing out from the village were obvious (as with the Danes, this reflected the political reality of the day, in which any foreign tribe, even one closely related, was a potential enemy). At the same time, human life was dependent upon such venturing out, minimally to obtain food and wood. Venturing out promised much greater rewards as well, to one who was lucky and worthy. As these worlds were full of dangerous other than human beings, they were filled as well with spiritual power that could be obtained by a questor. The more dangerous the being, the greater the potential power to be obtained. This power, called nawalakw by the Kwakiutl and Heiltsuk, was, when successfully brought back to the human realm, a source of prestige, wealth, and political power. It is similar to the Polynesian concept of mana, except that it always takes on a specific form, rather than being a generalizable quality of chiefs and nobles. Nawalakw is the essence of human sociability: it attracts wealth, as well as the respect and loyalty of comrades. Moreover, as a form of spiritual power, it prepares one to obtain further, more intense, forms of power. Thus, a chief's career followed a trajectory of obtaining first lesser and then greater forms of power (in post-myth times, this occurred through the inheritance and performance of ritual dances). The fact that the essential human value had to be obtained from a non-human, and even anti-human realm of being, demonstrates the profoundly dialectical quality of Northwest Coast thought.

Most striking of this dialectic turn of thought is the nature of other than human beings from which the greatest forms of nawalakw are obtained. These are possessed by two humanoid beings, which is to say monsters. In the Kwaiutl-Heiltsuk worldview, there exist altogether three humanoid beings outside the realm of human society. The first is inconsequential. It is the "Wild Man of the Woods," related to the cryptozoological Sasquatch, and possessing none of the cultural or material aspects of humanity. Thus, he lives alone in the woods, unclothed, lacking fire, reduced to foraging. He exhibits culture degré zéro, and is more the object of pity than fear. He nonetheless possesses a minor nawalakw. The two remaining figures are much more potent, and may be viewed as feminine and masculine transformations of the same principle. The female and lesser of these is Dzonokwa, often described as an ogress. She is characterized by two distinctive features: pendulous breasts and a mouth shaped like an O. The latter is her calling card, as she makes a hooting sound in the forest (much like the sound children will make, imitating apes and monkeys - it is a substitute for 
language, and an indication of its absence). Her pendulous breasts refer to her uncontrolled desire for children, and her illegitimate means of obtaining them. She is a sexual predator, existing outside the system of marriage rules and exchange. More commonly, though, she steals children, especially those who misbehave. She is thus a classic bogeyman, used to quiet fractious children, while teaching them the importance of behavior within cultural norms, for outside them exists only the chaos that she represents.

It is the final figure, the cannibal spirit, that represents the complete inversion of the Northwest Coast ethos. As with the Danes of Beowulf, the epitome of social life is feasting: sharing food among kindred and allies. This is seen as a sharing of land (chiefs owned productive salmon streams and other resources) and social identity. Feasting was so highly valued that on certain occasions it was considered appropriate to overeat to the point of vomiting (a tradition shared by the ancient Romans and modern celebrities). Like Grendel, the cannibal monster, Hamatsa, does not share food but takes the other for food. The spirit of the cannibal is a mythological creature known as Baxbakwalanusiwa, which Franz Boas translates as "cannibal at the north end of the world." He is encountered by a hunting party of brothers who are ascending a river valley up a mountain. In common with Nordic and Germanic peoples, the Northwest Coast people thought of the mountains as a spirit realm, most of whose denizens were malevolent towards humans (unlike the realm of the undersea world, which tended to be populated with more benign other than human beings). They are able to obtain the nawalakw from him, which they bring back to their village. It is the greatest of all the forms of nawalakw and provides the basis for the highest ranking dance in the Winter Ceremonial complex.

\section{The Winter Ceremonial: Admitting and Expelling Monsters}

The Winter Ceremonial, as practiced by the Kwakiutl, Heiltsuk, and neighboring tribes in central British Columbia, was documented by Boas in the mid-1890s (Boas 1966). The essential idea is that in the winter months the world, shaped like a dinner plate, flipped over, so that the dark world of dangerous other than human beings took priority over the human world (itself ascendant in the summer months). This unleashed an array of forces anathema to human existence: famine, pestilence, sexual anarchy, death itself, but above all the cannibal spirit. These noxious spirits each informed a dance society, which performed its dance to an audience consisting of the entire village or, in some cases, only the men. These societies were secret sodalities, which recruited initiates based primarily on heredity. The process began with initiates being forcibly taken from the village (generally with their 
cooperation) and taken out to the woods for a period of days or weeks to learn the secrets and to practice performance of the dance. They then return to the village (with the hamatsa dance generally serving as a sort of grande finale to the Winter Ceremonial), where they make a performance of their penchant for human flesh. This included actual biting of arms, the eating of dogs (serving as a stand in for human flesh) and the simulated or real (sources differ) cannibalism of human corpses.

In many ways, the hamatsa represents an inversion not only of the ethos of Kwakiutl and Heiltsuk society but even of the Winter Ceremonial itself. Most dances of the Winter Ceremonial involved masks, and sometimes elaborate costumes involving moving parts, puppets, multple surfaces, and other visual elaboration on a theme. The hamatsa alone danced nude or nearly so, with only rings of red cedar bark fabric representing the cannibal spirit. Indeed, the performance itself is remarkably simple: the dance is not elaborate and rather than a song there is merely a shout.

In a culture that valued dramatic performance above all else, this is striking. However, it is explainable in terms of the overall structure of the Winter Ceremonial. Of the various beings (many of which we could call monsters) on display, the most powerful and terrifying is the human element at the heart of it. Being human, there is no need to dissemble with masks; the essence of the cannibal is within us.

The logic of the Winter Ceremonial rests on the dialectic between human society and its negation. It plays this out dramatically, with the negative power being given free reign at first, then gradually and eventually tamed. The domestication of this antithetical power is the ultimate point of the ceremonial, but it happens only in fits and starts. At first, the hamatsa is pure appetite. He is controlled by a handler, lest he run amok. Language is one aspect of this process. Coming from a non-linguistic existence, the hamatsa gradually relearns human language. Ironically, this at first takes the limited form of only being able to recognize one word, which is a trigger-word for cannibalistic frenzy (it is usually a word for something common, such as «ant »). Members of the audience will intentionally utter the taboo word or more commonly a paraphrase so as to set the initiate off, and enjoy the result (a type of deep play in Clifford Geertz's terms). ${ }^{2}$

In addition to being refamiliarized with human language, the hamatsa initiate undergoes a physical transformation. Much like a hunter, who must purge his digestive tract of any traces 
of meat, lest the game animal will not allow itself to be killed, so too the hamatsa purges himself of remnants of human flesh. He fasts and vomits, using seawater as an emetic. Eventually he reaches a point at which he is capable of rejoining human society. Having endured the most powerful form of nawalakw represented in the Winter Ceremonial, he rejoins society at a place of privilege.

The Winter Ceremonial is in structure shamanic (with the Northwest Coast being very much within the arc of circumpolar shamanic cultures). An initiatory illness gives the shaman the power to overcome that illness and potentially all illness. Similarly, the Winter Ceremonial initiate is exposed to a very powerful nawalakw that is anathema to human society. The difference is, obviously, between the individual, bodily level at which the shaman operates, and the social level on which the initiate functions. Rather than becoming a healer (although the two were not mutually exclusive: shaman-hamatsas were particularly feared for their power), the hamatsa takes up a chiefly or noble role in society. He is thus responsible for upholding the values and norms of which the cannibal monster represents the negation.

As the hamatsa dancer is tamed and reintegrated into society, he celebrates this with a feast and potlatch. Here we see clearly the dialectical relation between these two poles: cannibalism and commensality. This is not so much a ritual of renunciation - cannibalism is not thought to be a natural urge, unlike for native groups to the east, especially the Ojibwa but rather a fundamental force to be overcome. As with any other seasonal ritual, such as those in agricultural societies, the triumph of light and life is of course only temporary. There is no final state, and indeed it would be a simplification of the subtlety of Northwest Coast thought to represent it this way.

Multiple perspectives are, indeed, what the Winter Ceremonial is primarily about. We see the two poles of the cannibal and chiefly charity, but we come to realize that these are two sides of the same coin. The chiefly feasts involve salmon, which must be killed and then eaten. But salmon is, in myth, itself human-like, and is associated especially with chiefs (who own salmon runs and of course give feasts of salmon). So from the perspective of the salmon people, who are organized into social groups identical to humans, the humans appear as cannibals. For them, this occurs in the summer months, when humans are fishing and storing salmon in for the winter. Such perspectivalism pervades Northwest Coast religious belief. The First Salmon ritual held in early summer is a means of addressing the problem of imbalance between the human and salmon worlds. By addressing the salmon with ritual words of respect, it is believed that the salmon agree to give themselves up (as they will be reborn if treated properly). However, the hamatsa also teaches us to be perhaps a little 
skeptical of such easy resolution of an existential dilemma. Culture is, as Nuckolls has said, a problem that cannot be solved.

\section{Didactic Monsters}

What, then, can monsters teach us? Monsters can teach us different sorts of lessons depending on their type. I suspect that dragons are there to teach us about fate, the ultimate resistance of the natural world to human intention, and the inevitability of death. It is the dragon that destroys Beowulf in the end. Dragons also possess great treasure, as indeed all human wealth derives from the natural world.

However, manlike monsters teach us about ourselves, via a sort of dialectical anthropology. Through them we learn what it means to be a Dane/Geat/Anglo-Saxon/Heiltsuk/Kwakiutl a human being. What this means is, first of all, a renunciation of alternative possibilities. Children are produced within regular and recognized marriage, not through incest, kidnapping, or rape. Hunger is satisfied via a complex ritual and technological system that involves prey and predator in reciprocal exchange, marked by ritual, not by taking the nearest person for food. Indeed, the essence of this cultural order entails the marking of difference as well as identity: the solidarity of the clan vs. sufficient distance for proper marriage, the species boundary that identifies food sources, ally vs. enemy, and so forth. Stories about monsters in these profoundly oral societies, in which philosophy and ethics, as well as history and politics, are loaded onto their oral literature, are about the world as it is, and why it must be that way.

\section{References Cited}

Bakhtin, Mikhail. 1981. The Dialogic Imagination. Edited by Michael Holquist. Austin: University of Texas Press.

Boas, Franz. 1966. Kwakiutl Ethnography. Edited by Helen Codere. Chicago: University of Chicago Press, 1966.

Earl, James W. 2010. "The Forbidden Beowulf: Haunted by Incest." PMLA: Publications of the Modern Language Association of America 125 (2): 289-305.

Freud, Sigmund. 1961. Civilization and Its Discontents. Translated by James Strachey. New York: W.W. Norton. 
Freud, Sigmund. 1919. "The Uncanny." Imago 5 (5-6): 297-324.

Friedman, John Block. 2000. The Monstrous Races in Medieval Art and Thought. Syracuse, NY: Syracuse University Press.

Graeber, David. 2001. Toward an Anthropological Theory of Value: The False Coin of Our Own Dreams. New York: Palgrave.

Hallowell, A. Irving. 1955. Culture and Experience. Philadelphia: University of Pennsylvania Press.

Harkin, Michael E. 1996. "Carnival and Authority: Heiltsuk Schemata of Power in Ritual Discourse." Ethos 24 (2), 281-313.

Harkin, Michael E. 1997. The Heiltsuks: Dialogues of History and Culture on the Northwest Coast. Lincoln: University of Nebrasa Press.

Harkin, Michael E. 2011. "John White and the Invention of Anthropology: Landscape, Ethnography, and Situating the Other in Roanoke." Histories of Anthropology Annual 7: 216-245.

Heaney, Seamus. 2008. Beowulf: An Illustrated Edition. New York: W.W. Norton.

Hymes, Dell. 1981. "In Vain I Tried to Tell You:" Essays in Native American Ethnopoetics. Lincoln: University of Nebraska Press.

Hymes, Dell. 2003. Now I Know Only So Far: Essays in Ethnopoetics. Philadelphia: University of Pennsylvania Press.

Jahoda, Gustav. 1999. Images of Savages: Ancient Roots of Modern Prejudice. New York: Routledge.

Lévi-Strauss, Claude. 1967. Structural Anthropology. Translated by Claire Jacobson and Brooke Grundfest Schoepf. Garden City, NY: Anchor Books.

Lévi-Strauss, Claude. 1983. Structural Anthropology, Vol. 2. Translated by Claire Jacobson. Chicago: University of Chicago Press.

Nuckolls, Charles. 1998. Culture: A Problem that Cannot Be Solved. Madison: University of Wisconsin Press.

Robinson, Fred C. 1991. "Beowulf." In The Cambridge Companion to Old English Literature, edited by Malcolm Godden and Michael Lapidge, 142-159. Cambridge: Cambridge University Press.

Tolkien, J.R.R. 1983. Beowulf: The Monsters and the Critics. London: George Allen and Unwin. 
Michael E. Harkin is professor of anthropology at the University of Wyoming. He received his Ph.D. from the University of Chicago. He has held two Fulbright fellowships, including a Distinguished Chair at the University of Graz. He has received three awards from the National Endowment for the Humanities, as well as fellowships from La Maison des Sciences de l'Homme in Paris and the University of North Carolina. He held the William Evans fellowship at the University of Otago. He was visiting professor at Shanghai University. $\mathrm{He}$ is past president of the American Society for Ethnohistory, and past editor of the journal Ethnohistory. He is currently Editor-in-chief of Reviews in Anthropology.

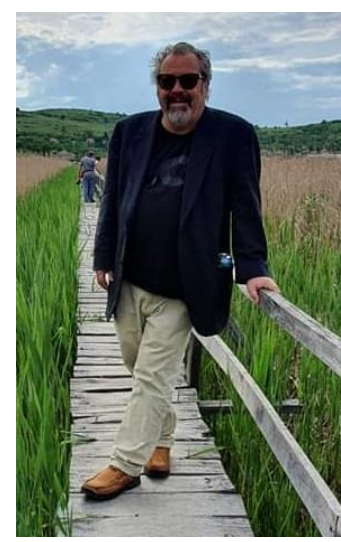

